\title{
Fossil lizards and snakes from Ano Metochi - a diverse squamate fauna from the latest Miocene of northern Greece
}

\author{
Georgios L. Georgalis ${ }^{\mathrm{a}, \mathrm{b}}$, Andrea Villa ${ }^{\mathrm{b}}$ and Massimo Delfino ${ }^{\mathrm{b}, \mathrm{c}}$ \\ aDepartment of Geosciences, University of Fribourg/Freiburg, Fribourg, Switzerland; 'bipartimento di Scienze della Terra, Università di Torino, Torino, \\ Italy; 'Institut Català de Paleontologia Miquel Crusafont, Universitat Autònoma de Barcelona, Edifici ICTA-ICP, Barcelona, Spain
}

\begin{abstract}
We here describe a new squamate fauna from the late Miocene (Messinian, MN 13) of Ano Metochi, northern Greece. The lizard fauna of Ano Metochi is here shown to be rather diverse, consisting of lacertids, anguids, and potential cordylids, while snakes are also abundant, consisting of scolecophidians, natricines and at least two different colubrines. If our identification is correct, the Ano Metochi cordylids are the first ones identified from Greece and they are also the youngest representatives of this group in Europe. A previously described scincoid from the adjacent locality of Maramena is here tentatively also referred to cordylids, strengthening a long term survival of this group until at least the latest Miocene. The scolecophidian from Ano Metochi cannot be attributed with certainty to either typhlopids or leptotyphlopids, which still inhabit the Mediterranean region. The find nevertheless adds further to the poor fossil record of these snakes. Comparison of the Ano Metochi herpetofauna with that of the adjacent locality of Maramena reveals similarities, but also striking differences among their squamate compositions.
\end{abstract}

\section{KEYWORDS}

Squamata; Miocene; extinction; taxonomy; biogeography

\section{Introduction}

Fossil squamate faunas from the southeastern edges of Europe are not well studied, despite the fact that they could play a pivotal role in our understanding of the biogeography and systematics of these reptiles. As such, although fossil lizards and snakes have been known from Greece since the nineteenth century (Owen 1857; Römer 1870; Weithofer 1888), they have only been sparsely documented (Schneider 1975; Szyndlar and Zerova 1990; Georgalis, Szyndlar et al. 2016; Georgalis, Villa, Delfino 2016).

The focus of this paper is the squamate fauna of the late Miocene (Messinian, MN 13) Ano Metochi-2 and Ano Metochi-3 localities in northern Greece. Fossil reptiles from Ano Metochi were previously undescribed, with the exception of an indeterminate natricine briefly mentioned by Szyndlar (1991b), and an agamid listed, erroneously, by Delfino et al. (2008, map in Figure 1) and Blain et al. (2016, map in Figure 4) (see Discussion below). The fossils described herein pertain to a diverse array of lizards and snakes and all originate from Ano Metochi-2 and Ano Metochi-3, two adjacent localities that were up to now mostly known for their micromammals (de Bruijn 1989; Koufos 2006).

Institutional Abbreviations: MDHC, Massimo Delfino Herpetological Collection, University of Torino, Italy; MNCN, Museo Nacional de Ciencias Naturales, Madrid, Spain; NHMW, Naturhistorisches Museum, Vienna, Austria; UU, University of Utrecht, Utrecht, Netherlands.

\section{Materials and methods}

All specimens described herein belong to the collection of the UU. Comparative material includes multiple skeletons of extant lizards and snakes housed in the MDHC, MNHN, MNCN and NHMW.

\section{Geological and palaeoecological settings}

Ano Metochi is situated next to the city of Serres, in the Serres Basin, Central Macedonia, northern Greece (Figure 1). Fossils have been found in two different localities, namely Ano Metochi-2 and Ano Metochi-3 (hereafter abbreviated as AM-2 and AM-3). The fossiliferous level of both AM-2 and AM-3, as well as that of the adjacent locality of Maramena, belong to the Lefkon Formation, characterized by conglomerates containing pebbles of schist, gneiss and granite (de Bruijn 1989). The geology of the Lefkon Formation and the adjacent ones (Georgios Formation and Spilia Formation) within the Serres Basis is described in detail by de Bruijn (1989). AM-2 and AM-3 are currently considered to be coeval and to be late Miocene (Messinian, MN 13) in age, whereas the adjacent Maramena is only slightly younger (MN 13 / 14) (Koufos 2006). Ano Metochi is mostly known for its diverse micromammal fauna, comprising lagomorphs, and sciurid, petauristid, cricetid, murid, gerbillid, spalacid and glirid rodents (de Bruijn 1989; Koufos 2006). Among large mammals, only the giraffid Helladotherium and two bovids, Prostrepsiceros woodwardi and an indeterminate species

CONTACT Georgios L.Georgalis georgios.georgalis@unifr.ch 


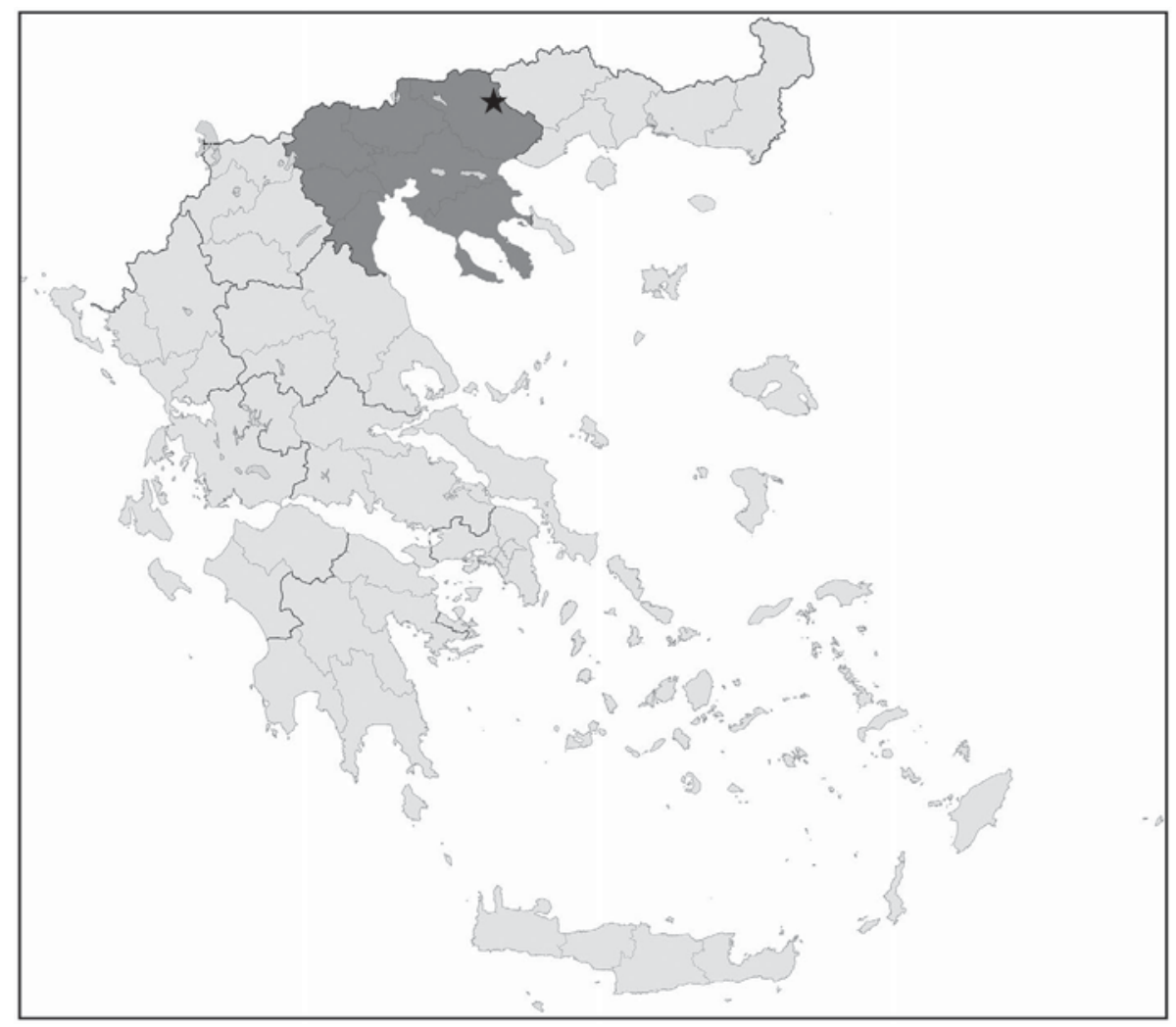

Figure 1. Map of Greece, indicating the localities of Ano Metochi (AM-2 and AM-3) studied in this paper.

of Gazella, have been reported so far from from Ano Metochi (Koufos 2006). Interestingly, different palaeoenvironments have been suggested for AM-2 and AM-3 on the basis of their micromammal fauna, with the former being considered to pertain to a wet and forest landscape, whereas the latter corresponding to a more dry and open environment (de Bruijn 1989).

Systematic Palaeontology

Squamata Oppel, 1811

Lacertidae Oppel, 1811

Lacertidae indet (Figure 2).

Material. AM-2: one fragment of a maxilla (UU AM2 501), three dentaries (UU AM2 502, UU AM2 503 and UU AM2 504), and two fragments of tooth-bearing bones (UU AM2 505). AM-3: one premaxilla (UU AM3 501), one maxilla (UU AM3 502) and one dentary (UU AM3 503).

Description. The premaxilla (UU AM3 501) is almost complete, lacking only the dorsal tip of the ascending nasal process. It is small-sized, with an alveolar plate that is $2.1 \mathrm{~mm}$ wide. It bears seven pleurodont, cylindrical and slender teeth, whose crown is not preserved. The postero-lateral tips of the palatal process are broken, but they are clearly separated by a wide and V-shaped notch. The incisive process is poorly developed. The ascending nasal process tends to slightly widen dorsally, but it does not show a leaf-shaped or an arrow-shaped morphology; its lateral margins are roughly subparallel in anterior view. A distinct septonasal crest is visible on the posterior surface of the process, whereas the anterior one is smooth.

The maxillae (UU AM3 502 and UU AM2 501) are represented by small fragments (UU AM3 502 is $3 \mathrm{~mm}$ in length, whereas UU AM2 501 is roughly $4.5 \mathrm{~mm}$ in length) bearing pleurodont, cylindrical and slender teeth. Ten tooth positions are recognizable in UU AM3 502, but only four teeth are preserved; all of them are bicuspid. UU AM2 501, on the other hand, bears three teeth and three empty tooth positions. In the latter specimen, tooth crowns are rather eroded, but one of the teeth seems to show two small accessory cusps by the sides of the main one. On the dorsal surface of the palatal shelf of both maxillae there is a very large superior dental foramen, followed by a wide and deep groove. The lateral surface of the fragments is smooth, with two ventrolateral foramina in both of them. Moreover, it is distinctly concave in UU AM2 501.

UU AM3 503, UU AM2 502, UU AM2 503 and UU AM2 504 are partially preserved dentaries, with missing the anteriormost and posteriormost parts. The length of the preserved portion of the specimens is $3.3 \mathrm{~mm}$ (UU AM3 503), $6.3 \mathrm{~mm}$ (UU AM2 502), 3 mm (UU AM2 503) and $6.7 \mathrm{~mm}$ (UU AM2 504). The dentaries are characterized by heterodont dentition and bear pleurodont and cylindrical teeth. Eight tooth positions are visible in UU AM3 503, ten in UU AM2 502, nine in UU AM2 503 and sixteen in UU AM2 504. The preserved teeth can be mono-, bi- or tricuspid. All teeth protrude well above the labial wall of the jaw. Also, teeth increase in basal diameter along the row, with the anteriormost having a narrower diameter than the posteriormost ones. The Meckelian fossa is moderately wide and opens medio-ventrally on the medial side of the bone. The lateral surface is smooth, with only three (Lac 002 and UU AM2 503) or six (UU AM2 504) labial foramina (not preserved in UU AM2 503), of which one is rather enlarged in UU AM3 503. 

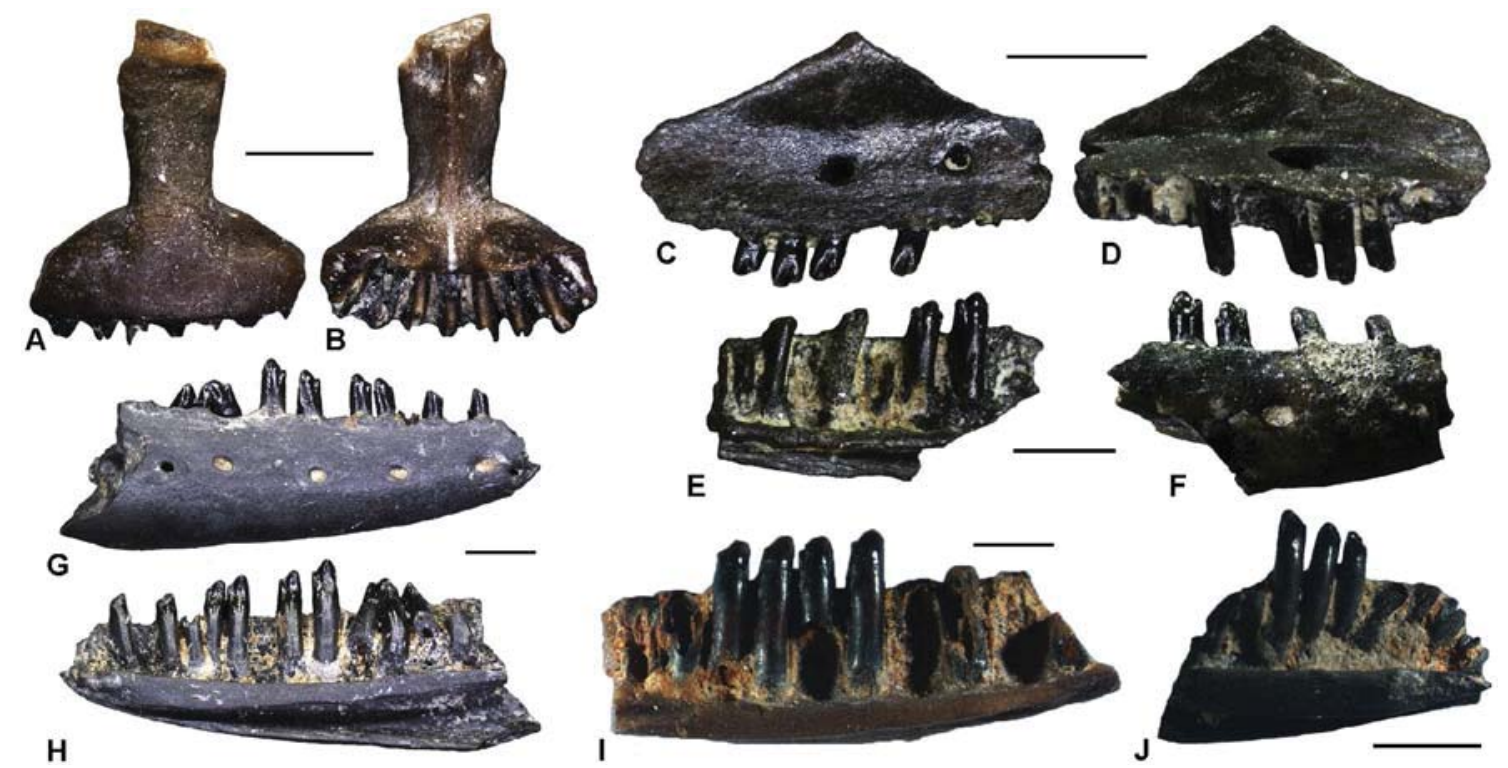

Figure 2. Lacertidae indet.: premaxilla (UU AM3 501) in anterior (A) and posterior (B) views; right maxilla (UU AM3 502) in lateral (C) and medial (D) views; right dentary (UU AM3 503) in medial (E) and lateral (F) views; right dentary (UU AM2 504) in lateral (G) and medial (H) views; right dentary (UU AM2 502) in medial (I) view; left dentary (UU AM2 503) in medial (J) view. Scale bars $=1 \mathrm{~mm}$.

The fragments of tooth-bearing bones are small-sized and poorly preserved. They bear pleurodont, cylindrical, slender and bicuspid teeth.

Remarks. The morphology of the teeth allows assignment of UU AM3 502, UU AM3 503 and UU AM3 501 to Lacertidae (Bailon 1991). The width of the alveolar plate of UU AM3 501 fits within the ranges defined by Barahona and Barbadillo (1997) for Iberolacerta bonnali, Podarcis bocagei, Podarcis hispanicus, and Podarcis muralis $(1.6 \mathrm{~mm}-2 \mathrm{~mm})$ and for Acanthodactylus erythrurus, Iberolacerta cyreni, Iberolacerta monticola, and Psammodromus algirus (2.3-2.4 mm). Moreover, according to the latter authors, seven tooth positions are a characteristic feature of the premaxillae of A. erythrurus, I. bonnali, Po. bocagei, Po. hispanicus, and Po. muralis, whereas the parallel lateral margins are typical of those of Algyroides marchi, I. bonnali, Po. bocagei, Po. hispanicus, Po. muralis, Ps. algirus, and Psammodromus hispanicus (Barahona and Barbadillo 1997). Accordingly so, UU AM3 501 seems to show affinities with the genus Podarcis and with $I$. bonnali. However, it has to be noted that the work of Barahona and Barbadillo (1997) is based only on Iberian lacertids and little is known about the comparative osteology of the small species inhabiting the eastern part of Europe today. Following a cautious approach, we can therefore attribute this specimen to a small-sized indeterminate lacertid, even if the possibility that it belongs to a juvenile of some other, larger species cannot be totally ruled out. As for UU AM3 502, UU AM3 503 and all the remains from AM-2, their fragmentary nature precludes any taxonomic assignment with certainty, but their size is consistent with a small-sized taxon. We cannot thus exclude neither the possibility that the material coming from the two localities pertains to the same taxon, nor that they represent two distinct lacertids from Ano Metochi.

Scincoidea Oppel, 1811

Cordylidae Gray, 1837

?Cordylidae indet (Figure 3).
Material. AM-2: one maxilla (UU AM2 507), two dentaries (UU AM2 508 and UU AM2 509), and one fragment of tooth-bearing bone (UU AM2 510). AM-3: two right maxillae (UU AM3 505, UU AM3 506) and one left maxilla (UU AM3 507).

Description. The four maxillae (UU AM2 507, UU AM3 505, UU AM3 506, and UU AM3 507; UU AM3 506 is broken into two portions) are not complete, but are moderately large in size (lengths are $7 \mathrm{~mm}$ for UU AM3 505, $5 \mathrm{~mm}$ for UU AM3 507, $8 \mathrm{~mm}$ for UU AM3 506, and $3.5 \mathrm{~mm}$-long for UU AM2 507). They bear moderately robust, pleurodont and cylindrical teeth, whose crowns are blunt and show lingual and labial longitudinal cusps separated by a groove (similar to the morphotype $\mathrm{F}$ of Kosma 2004). Moreover, the crowns are slightly curved in posteromedial direction and present striae on the lingual side. The preserved tooth positions are 10 for UU AM3 507, 13 for UU AM3 505, 20 for UU AM3 506, 6 for UU AM2 507, and all teeth are closely spaced. UU AM3 506, the most complete specimen, shows a low arched ridge on the medial surface of the anterior half of the facial process and a deep and moderately large superior dental foramen followed by a shallow groove. A similar superior dental foramen is visible also in UU AM3 507. In UU AM2 507, the arched ridge is well developed. The lateral surface of all specimens is smooth, with only a number of ventrolateral foramina (three in UU AM2 507, five in UU AM3 507 and seven in UU AM3 505 and UU AM3 506).

Tooth morphology of the two incomplete dentaries (UU AM2 507 and UU AM2 509) is similar to the above described maxillae, even if teeth are slightly more slender. Both specimens still preserve 9 tooth positions only. UU AM2 508 is $3.8 \mathrm{~mm}$-long, whereas UU AM2 509 is $3.4 \mathrm{~mm}$ in length. Both specimens are fragmentary and lack the posterior half, but UU AM2 509 preserves a narrow and horizontal mandibular symphysis. The Meckelian fossa is open medially. The lateral surface is smooth, with two (UU AM2 509) or four (UU AM2 508) labial foramina. 


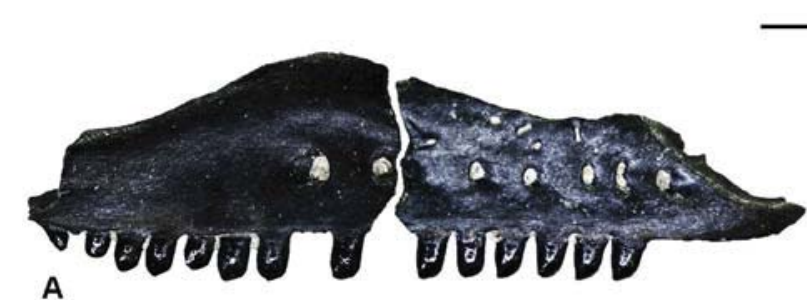

A

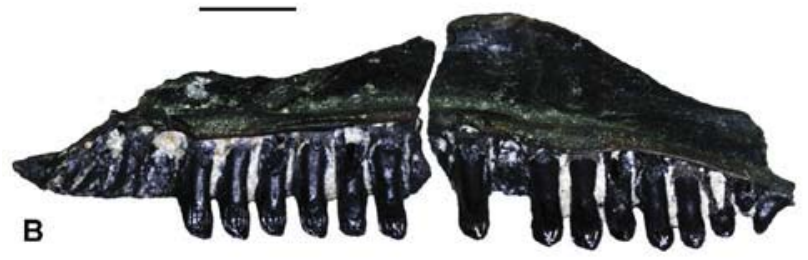

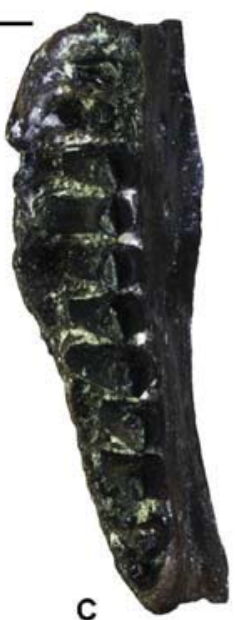

Figure 3. ?Cordylidae indet.: right maxilla (UU AM3 506) in lateral (A) and medial (B) views; left maxilla (UU AM3 507) in ventral (C) view; rigth dentary (UU AM2 508) in lateral (D) and medial (E) views; close-up of the teeth of UU AM3 506 in lingual view (F). Scale bars $=1 \mathrm{~mm}$.

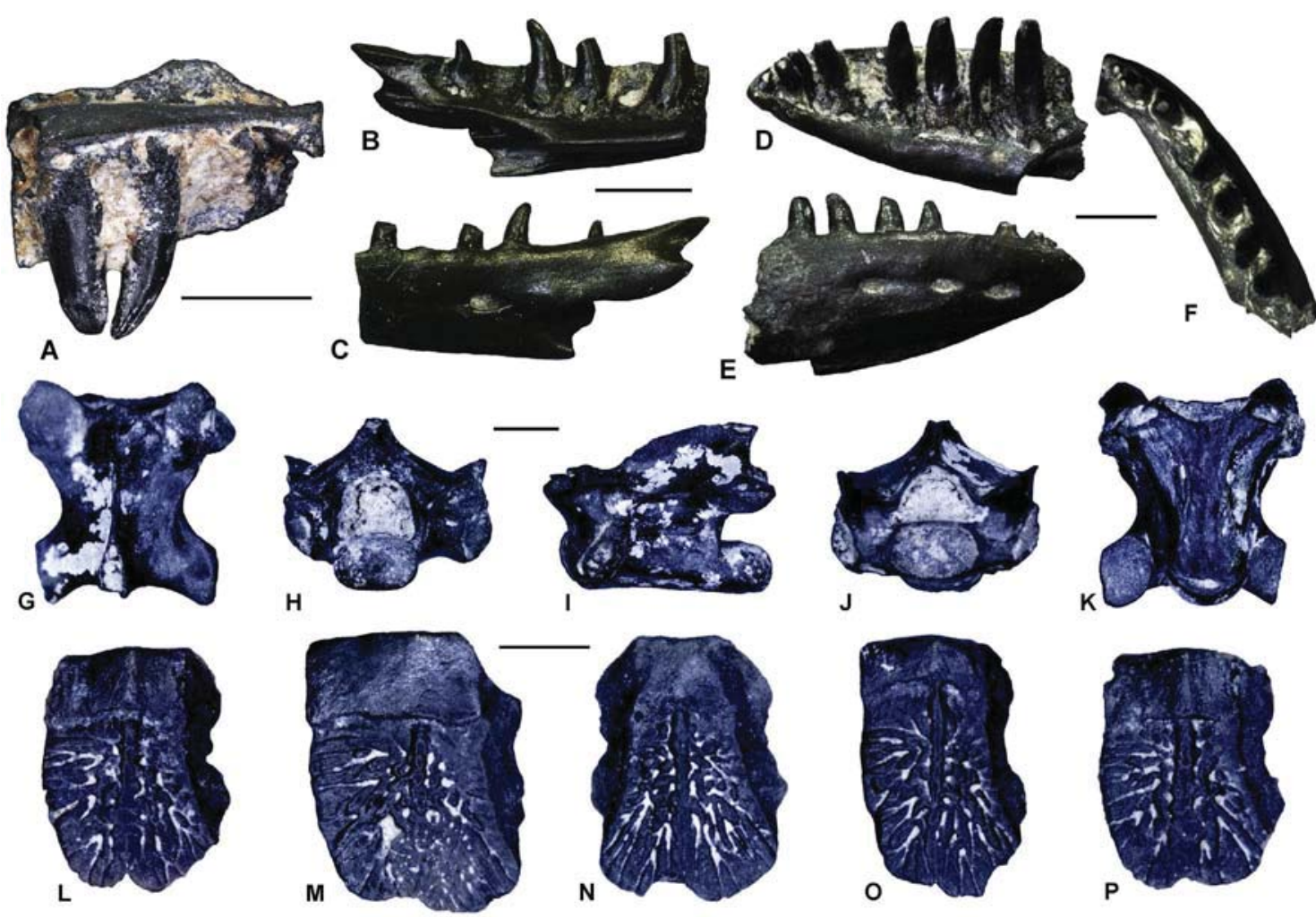

Figure 4. Ophisaurus sp.: left maxilla (UU AM2 512) in medial view (A); left dentary (UU AM3 510) in medial (B) and lateral (C) views; right dentary (UU AM3 512) in medial (D), lateral (E) and dorsal (F) views; presacral vertebra (UU AM3 513) in dorsal (G), posterior (H), left lateral (I), anterior (J) and ventral (K) views. Anguidae indet.: osteoderm (UU AM3 515) in dorsal (L) view; osteoderm (UU AM3 516) in dorsal (M) view; osteoderm (UU AM3 517) in dorsal (N) view; osteoderm (UU AM3 518) in dorsal (0) view; osteoderm (UU AM3 519) in dorsal (P) view. Scale bars $=1 \mathrm{~mm}$.

UU AM2 510 is a small fragment of tooth-bearing bone, which bears two teeth that are morphologically similar to the ones of UU AM2 507. It cannot be determined with certainty whether this material pertains to a dentary or a maxilla.

Remarks. Pleurodont implantation, cylindrical shape and bicuspid crown provided with lingual and labial longitudinal cusps and with striae on the lingual side are typical of the teeth of Scincoidea (sensu Estes et al. 1988 and Gauthier et al. 2012), including Cordyliformes (Cordylidae and Gerrhosauridae) and
Scincidae sensu lato (Kosma 2004). In gerrhosaurids, the striation is usually absent or poorly developed (Kosma 2004). A large number of cordylids and scincids, on the other hand, show this feature (Kosma 2004), but the distinction between the two families is often difficult (Čerňanský 2012). However, the remains from Ano Metochi, despite being incomplete have more robust teeth than those usually present in scincids and the striation is usually less distinct in the latter clade (Kosma 2004). Moreover, the above-described tooth morphology is similar to those shown 
by a left dentary from the early Miocene of Switzerland, figured by Jost et al. (2015, Figure 6(h)) and attributed to Bavaricordylus sp., as also by a right dentary from the early Miocene of Czech Republic, assigned to aff. Palaeocordylus bohemicus by Čerňanský (2012). Accordingly so, we here tentatively attribute the above described specimens from Ano Metochi to indeterminate cordylids. Interestingly, the scincoid taxon from the late Miocene of the nearby Maramena, described by Richter (1995, Figure 1(c) and (d)) as 'Scincoidea Incertae Sedis' bears strong resemblance with our Ano Metochi specimens, especially in terms of tooth morphology and the arrangement of the striae, and is here also tentatively referred to Cordylidae. Indeed, such a resemblance of the Maramena scincoid with primitive cordyliforms was already suggested by Richter (1995), who noted a similar arrangement pattern of the main striae of the teeth. In any case, if our identification is correct, these latest Miocene Greek forms from Ano Metochi and Maramena represent the youngest occurrence of Cordylidae from Europe.

Anguimorpha Fürbringer, 1900

Anguidae Gray, 1825

Anguinae Gray, 1825

Ophisaurus Daudin, 1803

Ophisaurus sp (Figure 4).

Material. AM-2: one fragment of a maxilla (UU AM2 512). AM-3: four dentaries (UU AM3 509, UU AM3 510, UU AM3 511 and UU AM3 512), 51 presacral vertebrae (UU AM3 513).

Description. UU AM2 512 is a rather small fragment of maxilla, carrying two sub-pleurodont teeth. A third, empty tooth position is visible. The preserved teeth are slender and slightly enlarged in their basis. One of them preserves the tip, which is pointed and slightly bending in posteromedial direction. There are no clear striae, but two sharp carinae are present both in the anterior and the posterior sides of the tip. The lateral surface of the fragment is slightly concave and bears two ventrolateral foramina.

The dentaries (UU AM3 509, UU AM3 510, UU AM3 511 and UU AM3 512) are small-sized and incomplete. UU AM3 512 represents the anterior end, UU AM3 510 is represented only by the posterior portion, UU AM3 511 preserves only the dorsal part of the posterior portion and UU AM3 509 lacks both the anterior and the posterior ends. All specimens are $4 \mathrm{~mm}$ in length, except for UU AM3 511 which is smaller (2.8 mm long). They bear sub-pleurodont, canine-like teeth, which are slightly posteromedially curved by their tip and slightly enlarged by their base. Teeth of UU AM3 512 are slightly more cylindrical and less enlarged. No striae can be seen on the lingual side of the teeth. Number of preserved tooth positions is 5 in UU AM3 511, 6 in UU AM3 510, 8 in UU AM3 509 and 9 in UU AM3 512. The Meckelian fossa (not preserved in UU AM3 511) is moderately narrow and opens ventromedially in UU AM3 509 and UU AM3 510 , but only ventrally in UU AM3 512, since a ventral expansion of the subdental shelf covers it laterally. The lateral surface is smooth, except for the presence of the mental foramina (one in UU AM3 510 and UU AM3 511, three in UU AM3 512 and four in UU AM3 509) and of a deep articulation surface for the angular. The mandibular symphysis (preserved only in UU AM3 512 ) is narrow and almost horizontal; its posterior end develops medially forming a short triangular expansion. The end of the intramandibular septum is visible in UU AM3 510 and UU AM3
511: it is located by the second posteriormost tooth position in the former and by the third posteriormost one in the latter. The posterior end of the same specimens presents a well developed coronoid process (although broken by the tip in the latter) and a less developed surangular process, separated by a moderately shallow coronoid incisure. The angular process (preserved only in UU AM3 510) seems not to develop beyond the posterior margin of the articulation surface with the angular, even though its tip could be broken. The surangular spine seems to be present but its posterior end is always broken and the splenial spine, when preserved, is poorly developed.

Presacral vertebrae (UU AM3 513) are small (centrum length 1.9-4 $\mathrm{mm}$ ) and have a dorsoventrally compressed centrum with distinctly convergent lateral margins. The neural canal is subtriangular in anterior view and the prezygapophyses and postzygapophyses are rounded and strongly tilted dorsally (about $45^{\circ}$ ). A well developed neural spine is present on the dorsal surface of the neural arch.

Remarks. The dorsoventrally compressed vertebral centrum with convergent lateral marginsclearly hint for the presence of a non-Anguis anguine taxon in Ano Metochi (Estes 1983). Furthermore, in a comparative study of the lower jaw of extant anguine genera, Klembara et al. (2014) stated that the presence of a surangular spine and of cylindrical and conical (canine-like) teeth slightly bending posteriorly by their tip distinguish dentaries of Ophisaurus from those of Anguis and Pseudopus (note that the latter authors considered Dopasia as a junior synonym of Ophisaurus; this taxonomic opinion is also followed here). The dentaries from Ano Metochi clearly do not belong to any of the extant species of the genus because of the absence of striae on the lingual side of the teeth and the poorly developed angular process (Klembara et al. 2014). Moreover, they can be differentiated from the extant species Ophisaurus koellikeri on the basis of their pointed end of the surangular process, from Ophisaurus ventralis on the basis of their coronoid process being longer than the surangular process, and from Ophisaurus attenuatus, Ophisaurus compressus, Ophisaurus mimicus and O. ventralis by the fact that the latter species have all their teeth slender (Klembara et al. 2014). Among fossil taxa, three species of Ophisaurus (including Dopasia) and related forms have been established on the basis of dentaries from the Oligocene of the Phosphorites du Quercy, France: Ophisaurus coderetensis, Ophisaurus frayssensis and Ophisaurus roqueprunensis (Augé 1992, 2005), with the former two having been recently reallocated to their own genus, Ophisauromimus (Čerňanský et al. in press). The dentaries from AM-3 differ from Ophisauromimus coderetensis in having a less marked coronoid incisure, from Ophisauromimus frayssensis in having a smaller size and less enlarged teeth, and from Ophisaurus roqueprunensis in having a surangular process shorter than the coronoid one and less enlarged teeth (Augé 1992, 2005). Eastern and Central European species of Ophisaurus have been erected based on parietals and therefore it is not possible to state if dentaries from AM-3 could belong to them or not. However, they differ from the ones attributed by Roček (1984) to Ophisaurus cf. spinari from Dolnice (early Miocene, MN 4), Czech Republic, because of shorter angular and surangular processes. The overall morphology of the herein described dentaries is similar to the one of those attributed to the 'Anguinae morphotype 2' from Merkur-Nord (early Miocene, MN 3), Czech Republic (Klembara 

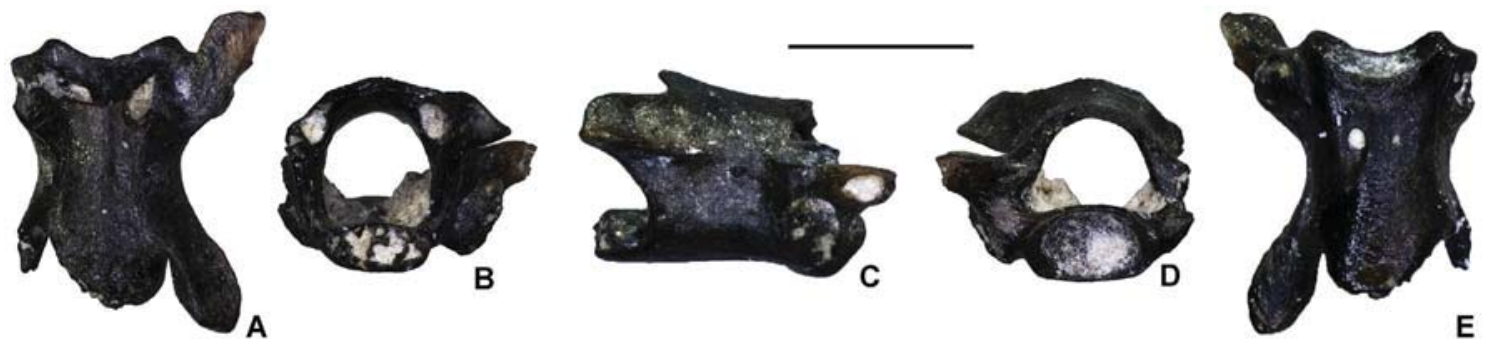

Figure 5. Scolecophidia indet.: precloacal vertebra (UU AM3 521) in dorsal (A), posterior (B), right lateral (C), anterior (D) and ventral (E) views. Scale bar = 1 mm.
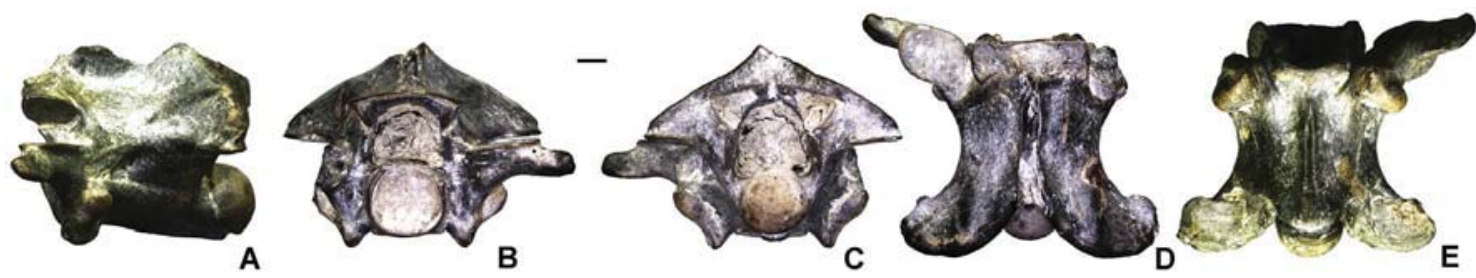

Figure 6. cf. Dolichophis sp.: precloacal vertebra (UU AM3 522) in left lateral (A), anterior (B), posterior (C), dorsal (D) and ventral (E) views. Scale bar = 1 mm.

2014) and to Ophisaurus sp. from Polgárdi (late Miocene, MN 13), Hungary (Venczel 2006). The latter locality has also yielded vertebrae and osteoderms that are similar in size and morphology to the ones from Ano Metochi (Venczel 2006).

Anguidae indet (Figure 4).

Material. AM-2: one fragment of an osteoderm (UU AM2 513). AM-3: 25 caudal vertebrae (UU AM3 514), and 41 osteoderms (UU AM3 515-UU AM3 520).

Description. Caudal vertebrae are small-sized (centrum length of the largest one is $3.9 \mathrm{~mm}$ ). Their centrum is dorsoventrally compressed and bears the proximal portions of fused haemapophyses. The autotomy plane is present.

Osteoderms (UU AM2 513 and UU AM3 515-UU AM3 520) are small, but moderately thick. They are subrectangular in shape and they show a low keel in the middle of their ornamented external surface. In UU AM2 513, the keel is distinct and sharp. Remarks. The subrectangular and thick osteoderms provided with a keel on the external surface indicates that they belong to a non-Anguis anguine. Furthermore, although it appears most probable that both osteoderms and caudal vertebrae belong to the same taxon described above (Ophisaurus sp.), this cannot be shown with certainty. We therefore refrain from formally assigning these elements to Ophisaurus, leaving even open the slight possibility that there is a second anguid present in Ano Metochi.

Serpentes Linnaeus, 1758

Scolecophidia Duméril et Bibron, 1844

Scolecophidia indet (Figure 5).

Material. AM-3: one precloacal vertebra (UU AM3 521).

Description. The precloacal vertebra UU AM3 521 is rather small, with a centrum length of only $1.2 \mathrm{~mm}$, and is missing the anterior and posterior margins of the neural arch, the left prezygapophysis and postzygapophysis, as well as the left synapophysis. The right prezygapophysis and postzygapophysis, the right synapophysis and the condyle are partially incomplete. The preserved postzygapophysis seems to be rather long and enlarged, extending well beyond the level of the condyle in ventral view. The anterior tip of prezygapophysis forms an angle of less than $10^{\circ}$ with the posterior tip of the postzygapophysis. The vertebra bears no hypapophysis or haemal keel. The neural arch is depressed and lacks a neural spine. The synapophysis is of hemispherical shape. Both cotyle and condyle are rather flattened dorsoventrally and their form is therefore strongly elliptical. No paracotylar foramina are present. As is common in scolecophidians, the neural canal is proportionally large, being much wider above the level of the cotyle, than below the level of the zygosphene. In lateral view, a large lateral foramen can be seen. There are two ventral foramina, of which one is rather enlarged.

Remarks. Rage (1984) and Szyndlar (1985, 1991a) discussed the uniform morphology of scolecophidian vertebrae that hinders their taxonomy. Their conservative vertebral anatomy has resulted in just a single named taxon of this clade from the whole European fossil record, 'Typhlops' grivensis (Hoffstetter 1946; Rage 1984). As is the case with most other Paleogene and Neogene European scolecophidians, the new Greek scolecophidian cannot be assigned with certainty to either Typhlopidae or Leptotyphlopidae. Moreover, the indeterminate scolecophidian from the Pliocene of Çalta, Turkey, described by Rage and Sen (1976) was not figured, and as such, no comparison with the Ano Metochi form can be made. The rather long and enlarged postzygapophyses of the new Greek vertebra, extending well beyond the level of the condyle in ventral view, seem to be distinctive; however, the current lack of knowledge regarding the anatomy and variability of scolecophidian vertebrae, hinders the potential taxonomic value of such a character. Whatever the case, the new vertebra described in this paper, is one among only a handful of known Neogene occurrences of the group worldwide (Mead 2013).

Alethinophidia Nopcsa, 1923

Colubridae Oppel, 1811

Colubrinae Oppel, 1811 (sensu Szyndlar, 1991a)

Dolichophis Gistel, 1868

cf. Dolichophis sp (Figure 6).

Material. AM-3: seven precloacal vertebrae (UU AM3 522-UU AM3 528). 
Description. The neural spine is only partially preserved in all vertebrae, but it appears that it was longer than high. The neural arch is vaulted. The centrum of the vertebrae is relatively elongated anteroposteriorly. The synapophyses are clearly differentiated into parapophyses and diapophyses, with the former being larger than the latter. Lateral foramina are present. The subcentral ridges and the haemal keel are prominent. In dorsal view, the neural spine appears to be thinner anteriorly than posteriorly. The zygosphene is slightly crenate and no median lobe is present, while the two lateral lobes are rather prominent. The prezygapophyseal articular facets are large and have a relatively oval shape. The prezygapophyseal processes are pointed distally. In anterior view, the neural canal is rather broad, being wider than the cotyle. The zygosphenal roof is thick. In posterior view, the postzygapophyseal processes are marked by small foramina. The zygantrum appears to be wider than the condyle, with the latter being slightly depressed.

Remarks. The presence or absence of a hypapophysis in the midtrunk vertebrae has been considered as the most significant character in distinguishing colubrine from natricine snakes (Szyndlar 1984, 1991a, 1991b). The specimens UU AM3 522-UU AM3 528 can be assigned to Colubrinae (sensu Szyndlar 1991b) by the combination of the following features: lightly built morphology, presence of haemal keel (and not of hypapophysis), synapophyses clearly divided into diapophyses and parapophyses, presence of lateral foramina, straight interzygapophyseal ridge, and straight subcentral ridge. Judging from the size of the largest vertebrae (CL: $6.2 \mathrm{~mm}$ for UU AM3 522, $5.9 \mathrm{~mm}$ for UU AM3 523, and $5.08 \mathrm{~mm}$ for UU AM3 524), the material pertains to a relatively large-sized colubrine snake, and it further bears strong resemblance with the extant Dolichophis, as also with 'Coluber' caspioides, a species originally described from the early Miocene of Petersbuch 2 (Szyndlar and Schleich 1993), with an additional referred form from the early Miocene of Merkur-Nord, Czech Republic (Ivanov 2002). It is worth noting that recently Szyndlar (2012) suggested that 'Coluber' caspioides should be probably referred, along with its similartaxa 'C.' suevicus, 'C.' dolnicensis and ' $C$.' pouchetii, to the extant genus Dolichophis, although he did not formally establish new generic combinations for his proposal. This option was later also followed by Venczel and Hír (2015) who described a similar form as 'Coluber' cf. caspioides from the middle Miocene of Litke 1, Hungary, although they also hesitated to formally assign this taxon to Dolichophis. In any case, the Ano Metochi large colubrine described herein bears strong vertebral resemblance to the complex 'Coluber' caspioides - ' $C$.' suevicus - 'C.' dolnicensis - 'C.' pouchetii, and is here tentatively assigned to cf. Dolichophis, rather than to the wastebasket taxon 'Coluber'.

Colubrinae indet (Figure 7).

Material. AM-3: eight precloacal vertebrae (UU AM3 529-UU AM3 538).

Description. The centrum is longer than wide. The neural spine is variably damaged in most specimens. The lateral foramina are distinct and they occur in deep depressions just ventral to the interzygapophyseal ridges. Synapophyses are clearly divided into parapophyses and diapophyses, with the former being rather laterally directed. In dorsal view, the zygosphene is variably convex or slightly crenate. The prezygapophyseal articular facets are rather broad. The prezygapophyseal processes of the largest vertebrae are rather short. In ventral view, the haemal keel continues anteriorly toward the base of the cotyle. Subcentral foramina are either present or absent, and there are even two small ones in UU AM3 531. The subcentral ridges are short and they are arched dorsally. In anterior view, the zygosphene roof is arched. Paracotylar foramina, when present, are situated in a deep depression next to the cotyle. Cotyle and condyle are slightly depressed and have an oval shape, in anterior and posterior views respectively.

Remarks. These vertebrae are attributed to Colubrinae by the combination of the absence of hypapophysis and presence of haemal keel, lightly built morphology, synapophyses clearly divided into diapophyses and parapophyses, presence of lateral foramina, straight interzygapophyseal ridge, and straight subcentral ridge (Szyndlar 1984, 1991a). This material corresponds to a smaller-sized and different colubrine taxon than the larger cf. Dolichophis sp. described above. Apart from their absolute size, the two Ano Metochi colubrines can be also distinguished from each other, by differences in their zygantral roof, prezygapophyseal and postzygapophyseal morphology.

Natricinae Bonaparte 1838 (sensu Szyndlar, 1991b)

Natrix Laurenti, 1768

Natrix sp (Figure 7).

Material. AM-2: 24 precloacal vertebrae (UU AM2 515). AM-3: 94 vertebrae (UU AM3 539), one compound bone (UU AM3 540), and one quadrate (UU AM3 541).

Description. All vertebrae bear well developed hypapophyses. In ventral view, the centrum is flattened and clearly delimited by prominent subcentral ridges. In several vertebrae, there are two enlarged subcentral foramina, located in both sides of the keel, at the middle of the centrum. Synapophyses are clearly divided into diapophyses and parapophyses bearing parapophyseal processes. The latter seem prominent and project anteroventrally. Prezygapophyseal processes are stout and the prezygapophyseal articular facets are oval shaped. The zygosphene is rather narrow and in dorsal view it appears to be slightly crenate. Both cotyle and condyle are rather rounded and enlarged, being larger than the neural canal. The neural spine variably damaged in all specimens, with few only exceptions. In all cases, the neural spine is longer than high in lateral view. Lateral foramina are enlarged.

The compound bone (UU AM3 540) lacks the anteriormost portion. The mandibular fossa is rather deep. The medial flange of the mandibular fossa is low. The labial flange is concave. The upper border of the labial flange is rather thickened.

In posterolateral view, the quadrate (UU AM3 541) is wide and flat. The bone is wider in the proximity of the trochlea quadrati and it expands towards the dorsal crest. The stapedial process is small and is indistinctly demarcated from the bone. The dorsal crest is thin and lacks the dorsoventral widening. The quadrate crest is prominent especially at middle length.

Remarks. The trunk vertebrae are assigned to Natricinae and in particular to the genus Natrix, on the basis of the presence of hypapophysis and the shape of the neural spine, the cranial margin of which overhangs anteriorly and the caudal margin overhangs posteriorly (Szyndlar 1984, 1991b; Ivanov 2002). The quadrate is assigned to the genus Natrix on the basis of the presence of the thin dorsal crest and the small stapedial process that is indistinctly demarcated from the bone (Ivanov 2002). The compound bone and the vertebral morphology are reminiscent 


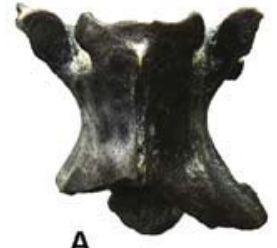

A
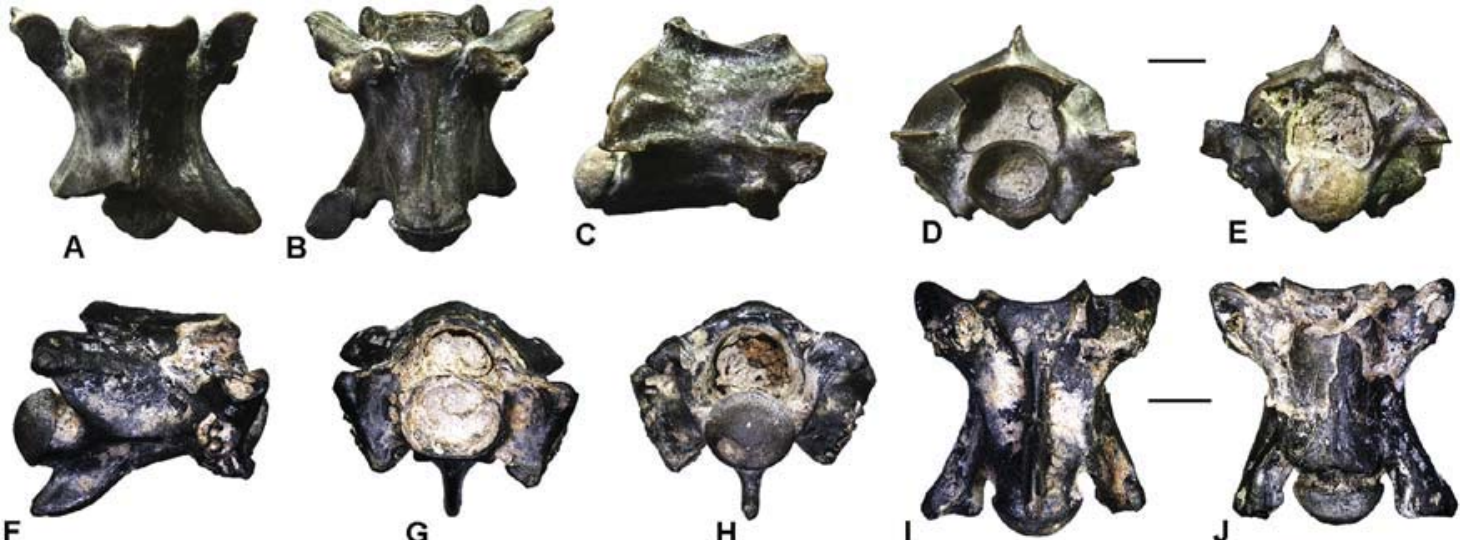

E
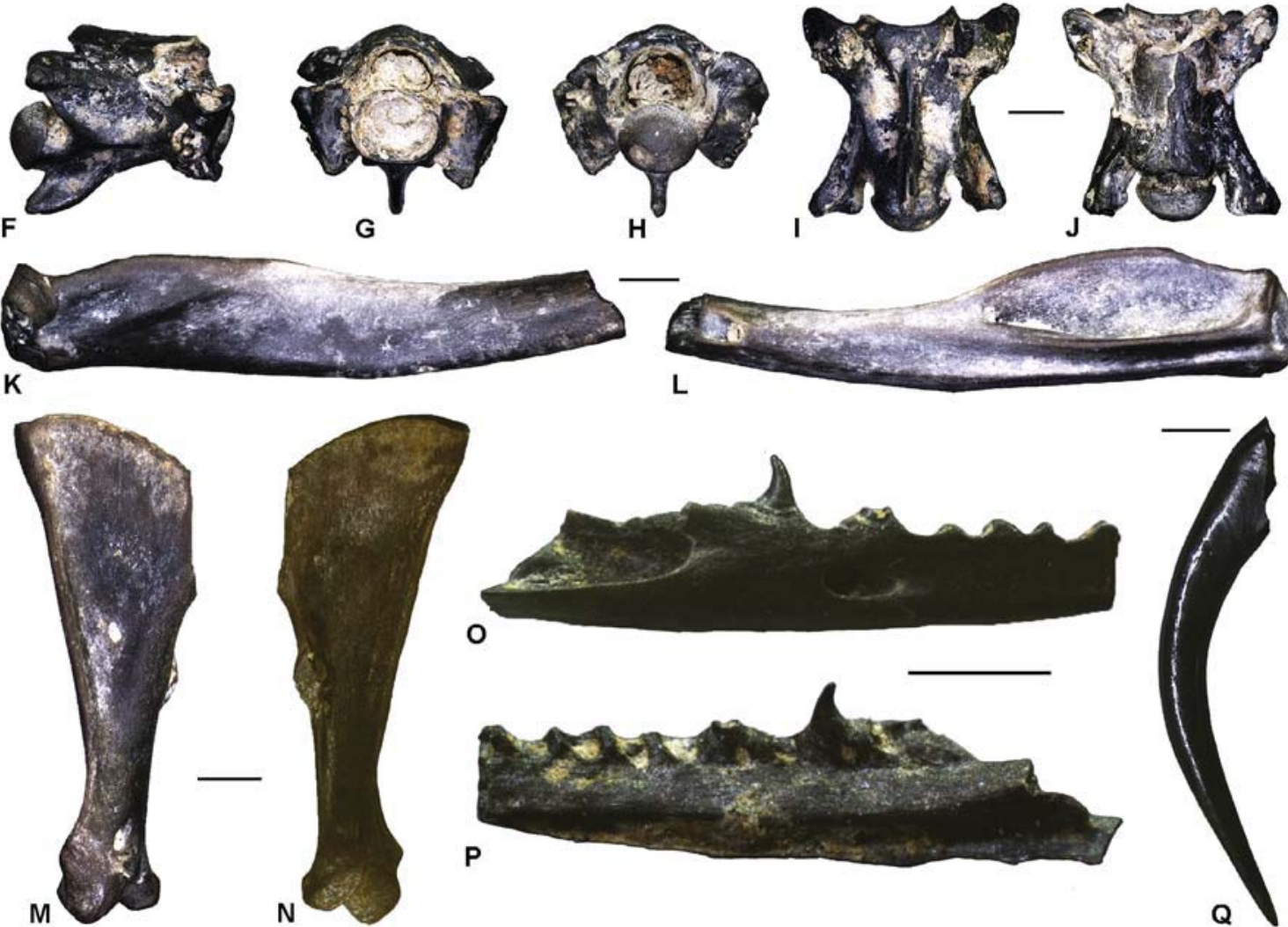

Figure 7. Colubrinae indet.: precloacal vertebra (UU AM3 529) in dorsal (A), ventral (B), right lateral (C), anterior (D) and posterior (E) views. Natrix sp.: precloacal vertebra (UU AM2 515) in right lateral (F), anterior (G), posterior (H), ventral (I) and dorsal (J) views; right compound bone (UU AM3 540) in medial (K) and lateral (L) views; left quadrate (UU AM3 541) in posterolateral (M) and anteromedial (N) views. Serpentes indet.: right dentary (UU AM2 516) in lateral (O) and medial (P) views; fang (UU AM3 547) (Q). Scale bars $=1 \mathrm{~mm}$.

to Natrix longivertebrata and $N$. aff. longivertebrata from the Pliocene of Poland and the Miocene of France respectively (Szyndlar 1984; Rage and Szyndlar 1986).

Serpentes indet (Figure 7).

Material. AM-2: one dentary (UU AM2 516), 35 precloacal vertebrae (UU AM2 517) and 11 caudal vertebrae (UU AM2 518). AM-3: four dentaries (UU AM3 542-UU AM3 545), one ?compound bone (UU AM3 546), several isolated fangs (UU AM3 547), 130 precloacal vertebrae (UU AM3 548), 46 caudal vertebrae (UU AM3 549), and 14 ribs (UU AM3 550).

Remarks. These various cranial and postcranial elements are either fragmentary or bear no clear diagnostic features that allow us to attribute them to any clade or make any proper identification. They are all considered to pertain to indeterminate snakes, that could belong also to one of the above described forms.

Squamata indet.

Material. AM-2: one fragment of a dentary (UU AM2 519), one fragment of tooth-bearing bone (UU AM2 520), one vertebra (UU AM2 521), and one fragment of a femur (UU AM2 522). AM-3: one fragment of a pterygoid (UU AM3 551), four vertebrae (UU AM3 552), two humeri (UU AM3 553 and UU AM3 554), and one ilium (UU AM3 555).

Remarks. Similarly to the case of the indeterminate snakes that was discussed above, this material does not bear diagnostic characters for identification beyond Squamata, and is here considered to pertain to indeterminate lizards (aka non-snake squamates).

\section{Discussion}

\section{Biogeography}

The Ano Metochi squamate fauna is quite diverse, being comprised of at least seven different species of lizards and snakes. Furthermore, this is one of a few only Miocene squamate localities described so far from Greece (Römer 1870; Weithofer 1888; Conrad et al. 2012; Georgalis, Villa and Delfino 2016; Georgalis, Villa, Vlachos et al. in press).

The purported presence of an agamid at AM-3, previously listed by Delfino et al. (2008) and Blain et al. (2016), is based on the misidentification of a specimen (UU AM3 557) belonging to a cyprinid fish. A similar erroneous attribution of a fish bone 
from the Pleistocene of Hungary to an agamid lizard was made by Meszoely and Gasparik (2002), as later noted by Rage (2013), prompting that cautiousness should be taken when identifying acrodont lizards.

With the exception of the probable cordylids, all squamate clades (lacertids, anguids, scolecophidians, colubrines and natricines) recovered from Ano Metochi still have extant representatives in Greece (Valakos et al. 2008; Sillero et al. 2014). On the other hand, fossil cordylids have never been described from that country and are now confined solely to Africa.

The fossil locality Maramena, which is located few kilometres away from Ano Metochi, provides a meaningful comparison, although it is slightly younger (MN 13/14). Maramena contains agamids, anguids (Ophisaurus), lacertids, scincoids (tentatively referred herein to cordylids), elapids and viperids (of the 'Oriental vipers complex') (Richter 1995; Szyndlar 1995). According to this faunal composition, lacertids and Ophisaurus are present in both Ano Metochi and Maramena. Also, as was noted above, the scincoid from Maramena described by Richter (1995) as 'Scincoidea Incertae Sedis' is here tentatively referred to Cordylidae, thus marking the shared presence of this clade in both Ano Metochi and Maramena. As such, it is obvious that lacertids, cordylids and Ophisaurus share a common presence in the late Miocene of the Serres Basin, reaching at least the MioPliocene boundary. On the other hand, agamids, elapids and 'Oriental vipers' are absent from the MN 13 stage (Ano Metochi) of the Serres Basin, whereas these clades are recovered at the end of MN 13 or the beginning of MN 14 (Maramena). Additionally, scolecophidians are present at the MN 13 stage, are then absent at the end of MN 13 or beginning of MN 14, and appear again in the Greek fossil record in the Plio-Pleistocene (Szyndlar 1991a). Agamids, scolecophidians and 'Oriental vipers' are still members of the Greek extant herpetofauna (Sillero et al. 2014), although it has not been clearly demonstrated that the distribution of the former is natural or due to anthropogenic factors in antiquity (Delfino et al. 2008). However, taking into consideration only these two localities, it is difficult to attest whether such faunal absences are genuine or simply an artifact of preservation or collection. Agamids have a wide distribution during the late Miocene of southern Europe, and are readily identified among lizard remains due to their characteristic acrodont dentition (Delfino et al. 2008). Scolecophidians are relatively small, their remains are difficult to collect, and they therefore have a poor fossil record (Mead 2013; Colombero et al. 2014), so it is possible that their absence in Maramena is due to preservation or collection biases. However, the case of elapids and 'Oriental vipers' is more complicated. These snake groups have several records from Miocene localities across Europe that are older than Maramena and Ano Metochi (Szyndlar and Rage 1990, 2002; Georgalis, Szyndlar et al. 2016a). The first descriptions of these groups from Greece is only in the late Miocene (MN 13 / 14) of Maramena (Szyndlar 1995), with elapids being recorded from the country also in the Pliocene and probably Pleistocene (Szyndlar 1991b), whereas 'Oriental vipers' are still members of the extant herpetofauna (Georgalis, Szyndlar et al. 2016). It is worth noting that elapids are also mentioned (without any description or figure) in a species list from the also northern Greek locality of 'Ravin de la Pluie' (MN 10) (de Bonis et al. 1991), and it is therefore impossible to reassess such a record or the correctness of its identity. As such, we can speculate that the absence of elapids and 'Oriental vipers' from Ano Metochi is genuine. In any case, however, this absence does not necessitate that these snake groups did not disperse to Greece prior to MN 13 (age of Ano Metochi). It is possible, in fact, that ecological factors did not favour the presence of cobras and large vipers at Ano Metochi.

\section{The rise and fall of European girdled lizards}

Girdled lizards (Cordylidae) constitute a bizarre clade of heavily armored squamates that are now confined to sub-saharan Africa. Despite their restricted extant distribution, the clade achieved a much wider distribution in the past, as it is demonstrated by its fossil record. Fossil cordylids are known with certainty from the early Miocene of The Czech Republic (Roček 1984; Čerňanský 2012) and Germany (Kosma 2004), and the middle Miocene (MN 5) of Austria (Böhme 2002), Germany (Böhme 2010) and Switzerland (Jost et al. 2015). In addition, certain occurrences from the Paleogene of Europe have been variously suggested as having affinities with cordyliforms. These include Eocordyla mathisi from the middle and late Eocene of France (Augé 2005), and 'Lacerta' rottensis from the late Oligocene of Germany (von Meyer 1856; Böhme and Lang 1991), as also other, unnamed forms from the late Eocene of Spain (Bolet and Evans 2013) and the late Oligocene of France (Augé and Rage 1995). The strong morphological resemblance of cordylid and scincid fossil remains may account for this low diversity and the poor record of the former clade. Future revisions may therefore show that several putative 'scincids' belong in fact to cordyliforms. In any case, the disjunct fossil distribution of cordyliforms has hindered our understanding of their palaeobiogeography. Different scenarios were created to explain their origins in Europe: either a continuous persistence of cordyliforms in Europe from the Eocene until the Miocene, or a late Paleogene extinction event of the primitive cordyliforms and then a re-dispersal of cordylids from Africa during the early Miocene, following the so-called 'Gomphotherium Landbridge' (Čerňanský 2012; Georgalis, Villa, Delfino 2016). The Ano Metochi cordylids cannot favor either of these scenarios. On the other hand, however, they reveal that cordyliforms persisted in Europe for much longer than what was previously thought, since up to now their younger described fossils had been recovered from the middle Miocene (MN 5) of Central Europe (Rage 2013). Therefore, if our identification of the herein described specimens is correct, the occurrence of cordylids in the much younger strata of the late Miocene Ano Metochi (MN 13) and the tentative referral of the Maramena (MN 13/14) form to this clade, implies a much longer survivorship and a possible withdrawal of their range to the southeastern margins of the continent. Interestingly, it seems that the Miocene southern Europe has variously marked the last occurrences for other reptile clades as well, as it has been previously suggested for podocnemidoidean turtles (Georgalis et al. 2013; Georgalis and Kear 2013) and somehow for crocodiles, even if in the latter case, dispersal from Africa is likely (Delfino and Rossi, 2013). The long term survival of cordylids could be explained by taking into consideration the ecology of extant girdled lizards, which mostly shelter in rock crevices or burrows (Bauer 1998), although Čerňanský (2012) considered that alternative ecological lifestyles for extinct cordylids could also be possible. 


\section{The diversity of Ophisaurus in the Neogene of Europe}

Anguis and Pseudopus are the only anguines that currently inhabit Europe, whereas species of Ophisaurus (sensu lato) are still present in northern Africa, southern Asia and North America. The main distinction between elements of Pseudopus and Ophisaurus is based on the tooth and parietal morphology, with the former genus distinguished by molariform posterior teeth, parietal characterized by an anterior branch of the parietal crest medially developed and the absence of a distinct parietal notch, whereas the latter bearing canine-like teeth, an anterior branch of the parietal crest laterally developed and a distinct parietal notch (Klembara 1979, 1981; Klembara et al. 2014). Klembara (1981) also mentioned some differences in the vertebral morphology of Pseudopus and Ophisaurus, with the vertebrae of the former being more robust and having straight lateral margins in the centrum, rather than concave ones as is the case for the latter genus. Despite their absence in the extant European herpetofauna, a large amount of Ophisaurus or Ophisaurus-like forms have been described from the fossil record of Europe, with their first appearance during the early Eocene of France (Augé et al. 1997). Since then, they continued to be present in several European Paleogene localities (Rage and Ford 1980; Augé 1992; Augé and Rage 1995; Böhme 2008; Augé and Smith 2009; Klembara and Green 2010; Čerňanský et al. 2016). Whether all these forms, however, constitute a single monophyletic lineage remains yet to be tested on the basis of complete phylogenetic analysis. During the Miocene Ophisaurus or Ophisaurus-like forms became widespread throughout Europe. Their remains have up to this date been recovered from Austria (Böhme 2002; Miklas-Tempfer 2003; Böhme and Vasilyan 2014), The Czech Republic (Klembara 1979, 1981, 2014; Roček 1984), France (Augé and Rage 2000; Rage and Bailon 2005), Germany (Jörg 1965; Prieto et al. 2009; Böhme 2010; Čerňanský et al. 2015), Hungary (Venczel 2006; Venczel and Hír 2015), Italy (Delfino 2002; Venczel and Sanchiz 2006; Rook et al. 2015), Portugal (Antunes and Mein 1981; Crespo 2001), Romania (Hír and Venczel 2005; Venczel et al. 2005; Venczel and Ştiucă 2008), Slovakia (Klembara 1986), Spain (Murelaga et al. 2002; Blain 2005), and Switzerland (Jost et al. 2015; Mennecart et al. 2016). Following the end of the Miocene the clade is in demise and their Pliocene record is scarce (Bailon 1989; Čerňanský 2011; Delfino et al. 2011). The last occurrence on the continent is reported from the Pleistocene of France (Clot et al. 1976) and Spain (Blain and Bailon 2010). The presence of Ophisaurus in Ano Metochi, along with the previously published record from Maramena, further confirms that, during the late Miocene, the genus had a widespread distribution across Europe, being also present in the southeastern margins of the continent. Greece is currently inhabited by four distinct anguid species: Anguis graeca, Anguis fragilis, Anguis cephallonica, and the largest European lizard, Pseudopus apodus (Sindaco and Jeremcenko, 2008; Gvoždík et al. 2010; Sillero et al. 2014).

\section{The Neogene scolecophidians of Europe}

Scolecophidians still occur in the extant Greek herpetofauna with Xerotyphlops vermicularis, which is also the sole representative of Typhlopidae in Europe. Leptotyphlopidae are not members of the extant European fauna, but still occur in the adjacent Asia Minor
(Adalsteinsson et al. 2012). In Europe, fossil scolecophidians are first described from the early Eocene of Dormaal, Belgium (Hecht and Hoffstetter 1962). After that, the clade is totally absent until the early Miocene, when it is recorded in France, Spain and The Czech Republic (Alférez and Brea 1981; Szyndlar 1987; Rage and Bailon 2005). During the Miocene and until the Pleistocene, scolecophidians have been sporadically recovered from localities across Europe (Szyndlar 1985; Hír and Venczel 2005; Szyndlar 2005; Venczel et al. 2005; Venczel and Ştiucă 2008; Venczel 2011; Colombero et al. 2014), showing a post-Pliocene southwarddirected decreasing trend of their range to the southeastern edges of Europe (Szyndlar 1991a; Rage 2013). This decrease in their range fully reflects their extant European distribution (southern Balkan Peninsula only), and is also consistent with similar southern European 'refugia' observed in other disparate reptile clades, such as erycine booids (Szyndlar 1991a; Rage 2013), and 'Oriental vipers' (Szyndlar and Rage 2002; Georgalis, Szyndlar et al. 2016). Fossil scolecophidians were already known from Greece, but they had only been recovered from Plio-Pleistocene sediments (Szyndlar 1991a). Thus, the new Ano Metochi form adds to the poor global Neogene record of the clade (Mead 2013).

Frustratingly, due to their conservative vertebral morphology and the scarcity of extant scolecophidian skeletal descriptions, it is rather difficult to attribute these occurrences to either typhlopids or leptotyphlopids. Moreover, the previously considered widespread extant genus Typhlops, has now been split into several genera on the basis of external morphology and strong molecular data, with Typhlops sensu stricto being now confined to the Caribbean, and the sole extant European representative assigned to its own genus, Xerotyphlops, along with three other species from the Sahara, Socotra Islands and southwestern Asia (Hedges et al. 2014; Pyron and Wallach 2014). This fact leaves the generic status of the until now single named species 'Typhlops' grivensis Hoffstetter, 1946 as uncertain, an attribution that was already first questioned by Rage (1984) who treated this taxon as ?Typhlops grivensis. We thus here treat the generic attribution of ' $T$.' grivensis in quotation marks, pending a redescription of the latter species.

\section{Conclusions}

Specimens of fossil squamates are described from the late Miocene (MN 13) of Ano Metochi, northern Greece. Systematic study of the material documents a diverse fauna consisting of lacertid, possible cordylid and anguid lizards, and scolecophidian, colubrine and natricine snakes that, with the exception of the latter constitute the oldest from Greece. The remains that were the origin of the erroneous identification of agamid lizards in previous publications have been here referred to cyprinid fish. A previously described scincoid from the adjacent locality of Maramena is herein tentatively referred to Cordylidae. The probable occurrence of girdled lizards (Cordylidae) in the latest Miocene of Greece is remarkable, as it constitutes the youngest records of the clade from Europe, implying a long term survivorship of a group that was previously thought to have become extinct around the middle Miocene (MN 5). The scolecophidian from Ano Metochi cannot be assigned to either Typhlopidae or Leptotyphlopidae, but adds to the poorly documented diversity of worm snakes. Comparison of the squamate faunas of the 
adjacent localities Ano Metochi and Maramena reveals shared faunal elements but also notable absences among these localities. The analysis and detailed description of the squamate remains from Ano Metochi allows us to expand and correct the knowledge of the reptile assemblage of this locality (previously limited to brief faunal lists) and therefore to enhance our understanding of Miocene reptile faunas of southeastern Europe.

\section{Acknowledgements}

We would like to acknowledge Wilma Wessels and Hans de Bruijn (University of Utrecht) and Borja Sanchiz (Museo Nacional de Ciencias Naturales, Madrid) for the loan of the specimens described in this paper. We also thank Walter Joyce (University of Fribourg), Dimitris Kostopoulos, George Koufos (Aristotle University of Thessaloniki) for their valuable comments that enhanced the quality of this manuscript. We also thank the Editor Gareth Dyke and Andrej Čerňansky and one Anonymous Reviewer for their Editorial and Reviewing process.

\section{Disclosure statement}

No potential conflict of interest was reported by the authors.

\section{Funding}

This work was supported by the study of comparative skeletal material of extant squamates funded by SYNTHESYS ES-TAF-5910 (Museo Nacional de Ciencias Naturales, Madrid) and SYNTHESYS AT-TAF-5911 (Naturhistorisches Museum, Vienna) grants to GLG and SYNTHESYS FR-TAF-5007 (Muséum national d'Histoire naturelle, Paris) to AV, and the curators of these institutions, respectively Marta Calvo-Revuelta, Heinz Grillitsch and Salvador Bailon, are also acknowledged here. Project supported by Fondi Ateneo Università di Torino (2014-2015) to MD.

\section{References}

Adalsteinsson SA, Branch WR, Trape S, Vitt LJ, Hedges SB. 2012. Molecular phylogeny, classification, and biogeography of snakes of the Family Leptotyphlopidae (Reptilia, Squamata). Zootaxa. 2244:1-50.

Alférez DF, Brea LP. 1981. Estudio preliminar de los restos de Peces, Anfibios y Reptiles del yacimiento mioceno de Córcoles (Guadalajara) [Preliminary study of the remains of fish, amphibians and reptiles in the Miocene deposit of Córcoles (Guadalajara)]. Boletin de la Real Sociedad Española de Historia Natural, Seccion Geologia. 79:5-20.

Antunes MT, Mein P. 1981. Vertébrés du miocène moyen de Amor (Leiria) - importance stratigraphique [The Vertebrates from the middle Miocene of Amor (Leiria) - stratigraphic importance]. Ciências da Terra. 6:169-188.

Augé ML. 1992. Une espéce nouvelle d'Ophisaurus (Lacertilia, Anguidae) de lOligocène des phosphorites du Quercy [One new species of Ophisaurus (Lacertilia, Anguidae) from the Oligocene of the Phosphorites of Quercy]. Révision de la sous-famille des Anguinae Paläontol Z 66:159-175.

Augé ML. 2005. Evolution des lézards du Paléogène en Europe [Evolution of lizards from the Paleogene of Europe]. Mémoires du Muséum national d'Histoire naturelle. 192:3-369.

Augé M, Rage J-C. 1995. Le Garouillas et les sites contemporains (Oligocene, MP 25) des Phosphorites du Quercy (Lot, Tarn-et-Garonne, France) et leurs faunes de vertebres. 2. Amphibiens et squamates [Le Garouillas and the contemporary sites (Oligocene, MP 25) from the Phosphorites of Quercy (Lot, Tarn-et-Garonne, France). 2. Amphibians and squamates]. Palaeontographica Abt A. 236:11-32.

Augé M, Rage J-C. 2000. Les Squamates (Reptilia) du Miocène moyen de Sansan [The squamates (Reptilia) from the middle Miocene of Sansan]. In: Ginsburg L, editor. La faune miocène de Sansan et son environnement [The Miocene fauna of Sansan and its environment]. Paris: Muséum national d'Histoire naturelle; p. 263-313.
Augé M, Smith R. 2009. An assemblage of early Oligocene lizards (Squamata) from the locality of Boutersem (Belgium), with comments on the Eocene-Oligocene transition. Zool J Linn Soc. 155:148-170.

Augé M, Duffaud S, Lappatrent de Broin F, Rage J-C, Vasse D. 1997. Les amphibiens et les reptiles de Prémontré (Cuisien, Bassin parisien): une herpétofaune de référence pour l'Eocène inférieur [The amphibians and reptiles of Prémontré (Cuisian, Paris Basin): one reference herpetofauna for the early Eocene]. Géologie de la France. 1:23-33.

Bailon S. 1989. Les amphibiens et les reptiles du Pliocène Supérieur de Balaruc II (Hérault, France) [Amphibians and reptiles from the Upper Pliocene of Balaruc II (Hérault, France)]. Palaeovertebrata. 19:7-28.

Bailon S. 1991. Amphibiens et Reptiles du Pliocène et du Quaternaire de France et d'Espagne: mise en place et évolution des faunes [Amphibians and reptiles from the Pliocene and Quaternary of France and Spain] [PhD dissertation]. Paris: Université de Paris VII.

Barahona F, Barbadillo LJ. 1997. Identification of some Iberian lacertids using skull characters. Rev Esp Herpetol. 11:47-62.

Bauer AM. 1998. Lizards. In: Cogger HG, Zweifel RG, editors. Encyclopedia of Reptiles and Amphibians. San Diego (CA): Academic Press; p. 126-173.

Blain H-A. 2005. Contribution de la paléoherpétofaune (Amphibia \& Squamata) à la connaissance de lévolution du climat et du paysage du Pliocène supérieur au Pléistocène moyen d'Espagne [Contribution of the palaeoherpetofauna (Amphibia \& Squamata) to the knowledge of climate change and landscape of the upper Pliocene and the Middle Pleistocene of Spain] [PhD dissertation]. Paris: Muséum national d'Histoire naturelle.

Blain H-A, Bailon S. 2010. Anfibios y escamosos del Pleistoceno inferior de Barranco León y de Fuente Nueva 3 (Orce, Andalucía, España) [Amphibians and squamates from the lower Pleistocene of Barranco León y de Fuente Nueva 3 (Orce, Andalucía, Spain)]. In: Toro I, Martínez-Navarro B, Agustí J, editors. Ocupaciones humanas durante el Pleistoceno inferior y medio de la Cuenca de Guadix-Baza [Human occupation during the lower and Middle Pleistocene of Cuenca de Guadix-Baza]. Arqueología Monografías. Junta de Andalucía: Sevilla; p. $165-183$.

Blain H-A, Bailon S, Agustí J. 2016. The geographical and chronological pattern of herpetofaunal Pleistocene extinctions on the Iberian Peninsula. C R Palevol. 15:761-744.

Böhme M. 2002. Lower Vertebrates (Teleostei, Amphibia, Sauria) from the Karpatian of the Korneuburg Basin - palaeoecological, environmental and palaeoclimatical implications. Beiträge zur Paläontologie. 27:339-354.

Böhme M. 2008. Ectothermic vertebrates (Teleostei, Allocaudata, Urodela, Anura, Testudines, Choristodera, Crocodylia, Squamata) from the Upper Oligocene of Oberleichtersbach (Northern Bavaria, Germany). Cour Forsch-Inst Senckenberg. 260:161-183.

Böhme M. 2010. Ectothermic vertebrates (Actinopterygii, Allocaudata, Urodela, Anura, Crocodylia, Squamata) from the Miocene of Sandelzhausen (Germany, Bavaria) and their implications for environment reconstruction and palaeoclimate. Paläontol Z. 84:3-41.

Böhme W, Lang M. 1991. The reptilian fauna of the Late Oligocene locality Rott near Bonn (Germany) with special reference to the taxonomic assignment of "Lacerta rottensis" Von Meyer, 1856. Neues Jahrb Geol Palaontol Abh Monatshefte H. 9:515-525.

Böhme M, Vasilyan D. 2014. Ectothermic vertebrates from the late Middle Miocene of Gratkorn (Austria, Styria). Palaeobiod Palaeoenv. 94:21-40.

Bolet A, Evans SE. 2013. Lizards and amphisbaenians (Reptilia, Squamata) from the late Eocene of Sossís (Catalonia, Spain). Palaentol Electronica. 16:1-23.

Bonaparte CL. 1832-1841. Iconographia della fauna Italica per le quattro classi degli animali vertebrati. Vol. 2. Anfibi. Rome (Italy): Dalla Tipografia Salviucci.

Čerňanský A. 2011. New finds of the Neogene lizard and snake fauna (Squamata: Lacertilia; Serpentes) from the Slovak Republic. Biologia. 66:899-911.

Čerňanský A. 2012. The oldest known European Neogene girdled lizard fauna (Squamata, Cordylidae), with comments on Early Miocene immigration of African taxa. Geodiversitas. 34:837-848.

Čerňanský A, Rage J-C, Klembara J. 2015. The Early Miocene squamates of Amöneburg (Germany): the first stages of modern squamates in Europe. J Syst Palaeontol. 13:97-128. 
Čerňanský A, Klembara J, Müller J. In press. The new rare record of the late Oligocene lizards and amphisbaenians from Germany and its impact on our knowledge of the European terminal Palaeogene. Palaeobiod Palaeoenv. doi:10.1007/s12549-015-0226-8.

Clot A, Chaline J, Jammot D, Mourer-Chauviré J, Rage J-C. 1976. Montousse 5 (Hautes-Pyrenees), un nouveau remplissage de fissure a faune de vertebres du Pleistocene inferieur [Montousse 5 (HautesPyrenees), one new fissure filling with a vertebrate fauna from the lower Pleistocene]. Geobios. 9:511-514.

Colombero S, Angelone C, Bonelli E, Carnevale G, Cavallo O, Delfino M, Giuntelli P, Mazza P, Pavia G, Pavia M, Repetto G. 2014. The Messinian vertebrate assemblages of Verduno (NW Italy): another brick for a latest Miocene bridge across the Mediterranean. Neues Jahrb Geol Palaontol Abh Monatschefte. 272:287-324.

Crespo EG. 2001. Paleoherpetofauna de Portugal [Palaeoherpetofauna of Portugal]. Publicações Avulsas, $2^{\circ}$ Série, numero 7. Lisbon (Portugal): Museu Bocage.

Conrad JL, Balcarcel AM, Mehling CM. 2012. Earliest example of a giant monitor lizard (Varanus, Varanidae, Squamata). PLoS ONE. 7(8):e41767.

de Bonis L, Bouvrain G, Geraads D, Koufos G. 1991. Diversity and paleoecology of Greek late Miocene mammalian faunas. Palaeogeogr Palaeoclimatol Palaeoecol. 91:99-121.

de Bruijn H. 1989. Smaller mammals from the Upper Miocene and lower Pliocene of the Strimon basin, Greece. Part 1. Rodentia and Lagomorpha. Boll Soc Paleontol Ital. 28:189-195.

Delfino M. 2002. Erpetofaune italiane del Neogene e del Quaternario [Italian herpetofaunas from the Neogene and the Quaternary] [PhD dissertation]. [Modena (Italy)]: University of Modena and Reggio Emilia.

Delfino M, Rossi MA. 2013. Fossil crocodylid remains from Scontrone (Tortonian, Southern Italy) and the late Neogene Mediterranean biogeography of crocodylians. Geobios. 46:25-31.

Delfino M, Kotsakis T, Arca M, Tuveri C, Pitruzzella G, Rook L. 2008 Agamid lizards from the Plio-Pleistocene of Sardinia (Italy) and an overview of the European fossil record of the family. Geodiversitas. 30:641-656.

Delfino M, Bailon S, Pitruzzella G. 2011. The late Pliocene amphibians and reptiles from "Capo Mannu D1 Local Fauna" (Mandriola, Sardinia Italy). Geodiversitas. 33:357-382.

Estes R. 1983. Sauria Terrestria, Amphisbaenia. In: Wellnhofer P, editor Encyclopedia of Paleoherpetology. Stuttgart / New York: Gustav Fisher Verlag; 249 pp.

Estes R, de Queiroz K, Gauthier J. 1988. Phylogenetic relationships within Squamata. In: Estes R, Pregill G, editors. Phylogenetic Relationships of the Lizard Families. Stanford: Stanford University Press; p. 119-282.

Gauthier JA, Kearney M, Maisano JA, Rieppel O, Behlke ADB. 2012. Assembling the squamate tree of life: perspectives from the phenotype and the fossil record. Bull Peab Mus Nat Hist. 53:3-308.

Georgalis GL, Kear BP. 2013. The fossil turtles of Greece: an overview of taxonomy and distribution. Geobios. 46:299-311.

Georgalis GL, Velitzelos E, Velitzelos, D, Kear BP. 2013. Nostimochelone lampra gen. et sp. nov., an enigmatic new podocnemidoidean turtle from the lower Miocene of northern Greece. In: Brinkman D, Holroyd P, Gardner J, editors. Morphology and evolution of turtles: papers in honor of Eugene S Gaffney Volume 3 Pleurodires. Dordrecht (The Netherlands): Springer; p. 277-287.

Georgalis GL, Szyndlar Z, Kear BP, Delfino M. 2016. New material of Laophis crotaloides, an enigmatic giant snake from Greece, with an overview of the largest fossil European vipers. Swiss Journal of Geosciences. 109:113-116.

Georgalis GL, Villa A, Delfino M. 2016. First description of a fossil chamaeleonid from Greece and its relevance for the European biogeographic history of the group. Sci Nat. 103:12.

Georgalis GL, Villa A, Vlachos E, Delfino M. In Press. Fossil amphibians and reptiles from Plakias, Crete: a glimpse into the earliest late Miocene herpetofaunas of southeastern Europe. Geobios. (accepted).

Gvoždík V, Jandzik D, Lymberakis P, Jablonski D, Moravec J. 2010. Slow worm, Anguis fragilis (Reptilia: Anguidae) as a species complex: genetic structure reveals deep divergences. Mol Phylogenet Evol. 55:460-472.
Hecht M, Hoffstetter R. 1962. Note préliminaire sur les amphibiens et les squamates du Landenien supérieur et du Tongrien de Belgique [A preliminary note on the amphibians and the squamates from the Landenians and the Tongrian of Belgium]. Bulletin de l'Institut royal des Sciences naturelles de Belgique. 38:1-30.

Hedges SB, Marion AB, Lipp KM, Marin J, Vidal N. 2014. A taxonomic framework for typhlopid snakes from the Caribbean and other regions (Reptilia, Squamata). Caribb Herpetol. 49:1-61.

Hír J, Venczel M. 2005. New middle Miocene vertebrate localities from Subpiatră (Bihor District, Romania). Acta Palaeontologica Romaniae. $5: 211-221$.

Hoffstetter R. 1946. Les Typhlopidae fossiles [The fossil Typhlopidae]. Bulletin du Muséum National d'Histoire Naturelle, Paris (Série 2) 18:309-315.

Ivanov M. 2002. The oldest known Miocene fauna from Central Europe: Merkur-North locality. Czech Republic Acta Palaeontol Pol. 47:513-534.

Jörg E. 1965. Ophisaurus acuminatus nov. spec. (Anguidae, Rept.) von der pontischen Wirbeltier-Fundstatte Hewenegg Hegau [Ophisaurus acuminatus nov. spec. (Anguidae, Rept.) from the Pontian of Wirbeltier-Fundstatte Hewenegg Hegau]. Beiträge zur naturkundlichen Forschungen in SW. Deutschland. 24:21-30.

Jost J, Kälin D, Börner S, Vasilyan D, Lawver D, Reichenbacher B. 2015. Vertebrate microfossils from the Upper Freshwater Molasse in the Swiss Molasse Basin: Implications for the evolution of the North Alpine Foreland Basin during the Miocene Climate Optimum. Palaeogeogr Palaeoclimatol Palaeoecol. 426:22-33.

Klembara J. 1979. Neue Funde der Gattungen Ophisaurus und Anguis (Squamata, Reptilia) aus dem Untermiozan Westbohmens (CSSR) [New finds of the genera Ophisaurus and Anguis (Squamata, Reptilia) from the Lower Miocene of West Bohemia (CSSR)]. Vestnik Ustrednıho ustavu geologickeho. 54:163-169.

Klembara J. 1981. Beiträg zur Kenntnis der Subfamilie Anguinae (Reptilia, Anguidae) [Contribution to the knowledge of the subfamily Anguinae] Acta Univ Carol, Geol. 2:121-168.

Klembara J. 1986. New finds of the genus Ophisaurus (Reptilia, Anguidae) from the Miocene of Western Slovakia (Czechoslovakia). Acta Univ Carol, Geol, Špinar. 2:187-203.

Klembara J. 2014. New finds of anguines (Squamata, Anguidae) from the Early Miocene of Northwest Bohemia (Czech Republic). Paläontol Z. 89:171-195.

Klembara J, Green B. 2010. Anguimorph lizards (Squamata, Anguimorpha) from the Middle and Upper Eocene of the Hampshire Basin of Southern England. J Syst Palaeontol. 8:97-129.

Klembara J, Hain M, Dobiašová K. 2014. Comparative Anatomy of the Lower Jaw and Dentition of Pseudopus apodus and the Interrelationships of Species of Subfamily Anguinae (Anguimorpha, Anguidae). Anat Rec. 297:516-544.

Kosma R. 2004. The dentitions of recent and fossil scincomorphan lizards (Lacertilia, Squamata) - systematics, functional morphology, paleocology [PhD dissertation]. [Hannover (Germany)]: University of Hannover.

Koufos GD. 2006. The Neogene mammal localities of Greece: faunas, chronology, and biostratigraphy. Ann Geol des Pays Helleniques. 4:183-214.

Laurenti, JN. 1768. Austriaci Viennensis specimen medicum, exhibens synopsin reptilium emendatam cum experimentis ca Venena et antidota reptilium Austriacorum quod authoritate et consensu. Vienna (Austria): Joannis Thomae de Trattnern, Caes. Reg. Maj. Aulae Typographi et Bibliopolae.

Linnaeus, C. 1758. Systema naturae per regna tria naturae, secundum classes, ordines, genera, species cum characteribus, differentiis, synonymis, locis. Tomus 1, Pars 1. Stockholm (Sweden): Laurentii Salvius.

Mead J. 2013. Scolecophidia (Serpentes) of the Late Oligocene and Early Miocene, North America, and a fossil history overview. Geobios. 46:225-231.

Mennecart B, Yerly B, Mojon P-O, Angelone C, Maridet O, Böhme M, Pirkenseer C. 2016. A new Late Agenian (MN2a, Early Miocene) fossil assemblage from Wallenried (Molasse Basin, Canton Fribourg, Switzerland). Paläontol Z. 90:101-123. 
Meszoely CAM, Gasparik M. 2002. First record of an agamid lizard from the Pleistocene of Hungary. Fragm Palaeontol Hung. 20:1-2.

Miklas-Tempfer PM. 2003. The Miocene Herpetofaunas of Grund (Caudata; Chelonii, Sauria, Serpentes) and Mühlbach am Manhartsberg (Chelonii, Sauria, Amphisbaenia, Serpentes), Lower Austria. Ann Naturhist Mus Wien. 104A:195-235.

Murelaga X, Pereda-Suberbiola X, Lapparent de Broin F, Rage J-C, Duffaud S, Astibia H. Badiola A.. 2002. Amphibians and reptiles from the Early Miocene of the Bardenas Reales of Navarre (Ebro Basin, Iberian Peninsula). Geobios. 35:347-365.

Nopcsa F. 1923. Die Familien der Reptilien [The families of the Reptiles] Fortschritte der Geologie und Paläontologie. 2:1-210.

Oppel M. 1811. Die Ordnungen, Familien und Gattungen der Reptilien als Prodom einer Naturgeschichte derselben. München (Germany): Joseph Lindauer Verlag.

Owen R. 1857. On the fossil vertebrae of a Serpent (Laophis crotaloides, Ow.) discovered by Capt. Spratt, R.N., in a tertiary formation at Salonica. Quarterly Journal of the Geological Society of London. 13:196-199.

Prieto J, Böhme M, Maurer H, Heissig K, Abdul-Aziz H. 2009. Biostratigraphy and sedimentology of the Fluviatile Untere Serie (Early and Middle Miocene) in the central part of the North Alpine Foreland Basin: implications for palaeoenvironment and climate. Int J Earth Sci. 98:1767-1791.

Pyron RA, Wallach V. 2014. Systematics of the blindsnakes (Serpentes: Scolecophidia: Typhlopoidea) based on molecular and morphological evidence. Zootaxa. 3829:1-081.

Rage J-C. 1984. Serpentes. In: Wellnhofer P, editor. Encyclopedia of paleoherpetology. Stuttgart / New York: Gustav Fisher Verlag.

Rage J-C. 2013. Mesozoic and Cenozoic squamates of Europe. Palaeobiod Palaeoenv. 93:517-534.

Rage J-C, Bailon S. 2005. Amphibians and squamate reptiles from the late early Miocene (MN 4) of Béon 1 (Montréal-du-Gers, southwestern France). Geodiversitas. 27:413-441.

Rage J-C, Ford RLE. 1980. Amphibians and squamates from the Upper Eocene of the Isle of Wight. Tertiary Research. 3:47-60

Rage J-C, Sen S. 1976. Les Amphibiens et les Reptiles du Pliocène supérieur de Çalta (Turquie) [The amphibians and the reptiles from the upper Pliocene of Çalta (Turkey)]. Géologie méditerranéenne. 3:127-134.

Rage J-C, Szyndlar Z. 1986. Natrix longivertebrata from the European Neogene, a snake with one of the longest known stratigraphic ranges. Neues Jahrb Geol Palaontol Mh. 1986:56-64.

Richter A. 1995. The vertebrate locality Maramena (Macedonia, Greece) at the Turolian-Ruscinian Boundary (Neogene). 3. Lacertilia (Squamata, Reptilia). Münchner Geowiss Abh. 28:35-38.

Roček Z. 1984. Lizards (Reptilia, Sauria) from the lower Miocene locality Dolnice (Bohemia, Czechoslovakia). Rozpravy Ceskoslovenské Akademie Ved, Rada matematickych a prirodnich Ved. 94:1-66.

Römer F. 1870. Über Python euboicus, eine fossile Riesenschlange aus tertiärem Kalkschiefer von Kumi auf der Insel Euboea [On Python euboicus, a fossil giant snake from the tertiary shale of Kumi in the island of Euboea]. Z Dtsch geol Gesell. 22:582-590.

Rook L, Delfino M, Sami M. 2015. I vertebrati fossili della cava del Monticino di Brisighella: una finestra sui popolamenti continentali del Mediterraneo nel Miocene superiore. I gessi di Brisighella e Rontana [The fossil vertebrates from the cave of Monticino di Brisighella: one window to the Mediterranean continental populations in the upper Miocene: the sediments of Brisighella and Rontana]. Memorie dell'Istituto Italiano di Speleologia s II, 28:79-100.

Schneider B. 1975. Ein mittelpleistozane Herpetofauna von der Insel Chios, Agais [A middle Pleistocene herpetofauna from the island of Chios, Aegean]. Senckenb Biol. 56:191-198.
Sillero N, Campos J, Bonardi A, Corti C, Creemers R, Crochet P-A, Crnobrnja Isailović J, Denoël M, Ficetola GF, Gonçalves J, et al. 2014. Updated distribution and biogeography of amphibians and reptiles of Europe. Amphibia-Reptilia. 35:1-31.

Sindaco R, Jeremčenko V. 2008. The reptiles of the western Palearctic Vol 1: annotated checklist and distributional atlas of the turtles, crocodiles, amphisbaenians and lizards of Europe, North Africa, Middle East and Central Asia. Belvedere: Monografie della Societas Herpetologica Italica I.

Szyndlar Z. 1984. Fossil snakes from Poland. Acta Zoologica Cracoviensia. 28:1-156.

Szyndlar Z. 1985. Ophidian fauna (Reptilia, Serpentes) from the Uppermost Miocene of Algora (Spain). Estud Geol. 41:447-465.

Szyndlar Z. 1987. Snakes from the lower Miocene locality of Dolnice (Czechoslovakia). J Vert Paleontol. 7:55-71.

Szyndlar Z. 1991a. A review of Neogene and Quaternary snakes of Central and Eastern Europe. Part I: Scolecophidia, Boidae. Colubrinae Estud Geol. 47:103-126.

Szyndlar Z. 1991b. A review of Neogene and Quaternary snakes of Central and Eastern Europe. Part II: Natricinae, Elapidae. Viperidae Estud Geol. $47: 237-266$

Szyndlar Z. 1995. The vertebrate locality Maramena (Macedonia, Greece) at the Turolian-Ruscinian Boundary (Neogene). 4. Serpentes (Squamata, Reptilia). Münchner Geowiss Abh. 28:35-39.

Szyndlar Z. 2005. Snake fauna from the Late Miocene of Rudabánya. In: Bernor RL, Kordos L, Rook L, editors. Multidisciplinary research at Rudabánya Palaeontogr ital 90:31-52.

Szyndlar Z. 2012. Early Oligocene to Pliocene Colubridae of Europe: a review. Bull Soc géol France. 183:661-681.

Szyndlar Z, Rage J-C. 1990. West Palearctic cobras of the genus Naja (Serpentes: Elapidae): interrelationships among extinct and extant species. Amphibia-Reptilia. 11:385-400.

Szyndlar Z, Rage J-C. 2002. Fossil record of the true vipers. In: Schuett G, Hoggren M, Douglas M, Greene H, editors. Biology of the Vipers. Eagle Mountain: Eagle Mountain Publishing; p. 419-441.

Szyndlar Z, Schleich HH. 1993. Description of Miocene snakes from Petersbuch 2 with comments on the lower and middle Miocene ophidian faunas of southern Germany. Stuttgarter Beiträge zur Naturkunde B. 192:1-47.

Szyndlar Z, Zerova G. 1990. Neogene cobras of the genus Naja (Serpentes: Elapidae) of East Europe. Ann Naturhist Mus Wien. 91A:53-61.

Valakos ED, Pafilis P, Sotiropoulos K, Lymberakis P, Maragou P, Foufopoulos J. 2008. Amphibians and reptiles of Greece. Frankfurt (Germany): Chimaira.

Venczel M. 2006. Lizards from the late Miocene of Polgárdi (W-Hungary). Nymphaea: Folia naturae Bihariae 33:25-38.

Venczel M. 2011. Middle-Late Miocene snakes from the Pannonian basin. Acta Palaeontologica Romaniae. 7:343-349.

Venczel M, Hír J. 2015. Lissamphibians and squamate reptiles from the early middle Miocene of Litke. Northern Hungary Geobios. 48:491-504.

Venczel M, Sanchíz B. 2006. Lower Miocene Amphibians and Reptiles from Oschiri (Sardinia, Italy). Hantkeniana. 5:72-75.

Venczel M, Ştiucă E. 2008. Late middle Miocene amphibians and squamate reptiles from Taut. Romania Geodiversitas. 30:731-763.

Venczel M, Hir J, Huza RR, Popa E, Golban G. 2005. A new Middle Miocene vertebrate fauna from Subpiatrã (Bihor County, Romania). Nymphaea: Folia naturae Bihariae. 32:23-38.

von Meyer H. 1856. Letter on various fossil vertebrates. Neues Jahrb Geol Palaontol Abh. 1856:824-829.

Weithofer A. 1888. Beiträge zur Kenntniss der Fauna von Pikermi bei Athen [Contribution to the knowledge of the fauna of Pikermi in Athens]. Beiträge zur Paläontologie Österreich-Ungarns. 6:225-292. 